\title{
Soil and water losses in eucalyptus plantation and natural forest and determination of the USLE factors at a pilot sub-basin in Rio Grande do Sul, Brazil
}

\section{Perdas de solo e água em plantios de eucalipto e floresta nativa e determinação dos fatores da USLE em sub-bacia hidrográfica piloto no Rio Grande do Sul, Brasil}

\author{
Bárbara Pereira Christofaro Silva ${ }^{1 *}$, Marx Leandro Naves Silva ${ }^{2}$, Pedro Velloso Gomes Batista ${ }^{2}$, \\ Lucas Machado Pontes², Elias Frank Araújo $^{3}$, Nilton Curi²
}

\author{
${ }^{1}$ Universidade Federal de Lavras/UFLA, Departamento de Ciência do Solo/DCS, Lavras, MG, Brasil \\ ${ }^{2}$ Universidade Federal de Lavras/UFLA, Lavras, MG, Brasil \\ ${ }^{3}$ CMPC Celulose do Brasil Ltda., Guaíba, RS, Brasil \\ *Corresponding author: barbarapcsilva@yahoo.com.br \\ Received in April 4, 2016 and approved in June 6, 2016
}

\begin{abstract}
Monitoring water erosion and the factors that control soil and water loss are essential for soil conservation planning. The objective of this study was to evaluate soil and water losses by water erosion under natural rainfall in eucalyptus plantations established in 2001 (EF2), and 2004 (EF1), native forest (NF) and bare soil (BS), during the period of 2007 to 2012; and to determine the USLE factors: rain erosivity $(\mathrm{R})$, erodibility (K) of a Red Argisol and the cover-management factor (C) for EF1, EF2 and NF at a pilot sub-basin, in Eldorado do Sul, RS, Brazil. The $\mathrm{R}$ factor was estimated by the $\mathrm{El}_{30}$ index, using rainfall data from a gauging station located at the sub-basin. The soil and water losses were monitored in erosion plots, providing consistent data for the estimation of the $\mathrm{K}$ and $\mathrm{C}$ factors. The sub-basin presented an average erosivity of 4,228.52 MJ mm ha-1 $\mathrm{h}^{-1} \mathrm{yr}^{-1}$. The average annual soil losses em EF1 and EF2 (0.81 e $0.12 \mathrm{Mg}^{-1} \mathrm{ha}^{-1}$ year ${ }^{-1}$, respectively) were below of the limit of tolerance, $12.9 \mathrm{Mg} \mathrm{ha}^{-1} \mathrm{year}^{-1}$. The percentage values of water loss relating to the total rainfall decreased annually, approaching the values observed at the NF. From the 5 th year on after the implantation of the eucalyptus systems, soil losses values were similar to the ones from NF. The erodibility of the Red Argisol was of $0.0026 \mathrm{Mg}$ ha h ha-1 $\mathrm{MJ}^{-1} \mathrm{~mm}^{-1}$ and the $\mathrm{C}$ factor presented values of $0.121,0.016$ and 0.015 for EF1, EF2 and NF, respectively.
\end{abstract}

Index terms: Water erosion; soil erodibility; rainfall erosivity; cover-management factor.

\begin{abstract}
RESUMO
O monitoramento da erosão hídrica e o conhecimento dos fatores que causam perdas de solo e água são essenciais para o planejamento conservacionista do solo. Objetivou-se com esse trabalho avaliar as perdas de solo e água por erosão hídrica, sob chuva natural, em plantios de eucalipto estabelecidos em 2001 (FE2) e 2004 (FE1), floresta nativa (FN) e solo descoberto (SD), no período de 2007 a 2012; e determinar os fatores da USLE: erosividade da chuva (R), erodibilidade (K) de um Argissolo Vermelho e o fator cobertura vegetal (C) para FE1, FE2 e FN, em sub-bacia hidrográfica piloto, em Eldorado do Sul, RS. O fator R foi estimado pelo índice $\mathrm{El}_{30}$, a partir de dados pluviométricos obtidos em estação climatológica instalada na sub-bacia. As perdas de solo e água foram monitoradas em parcelas experimentais, fornecendo dados consistentes para a estimativa dos fatores K e C. A sub-bacia apresentou uma erosividade média de $4.228 .52 \mathrm{MJ} \mathrm{mm}$ ha $^{-1} \mathrm{~h}^{-1} \mathrm{ano}^{-1}$. As perdas médias anuais de solo em FE1 e FE2 (0.81 e $0.12 \mathrm{Mg} \mathrm{ha}^{-1}$ ano-1, respectivamente) foram muito abaixo do limite de tolerância 12,9 Mg ha-1 ano-1. Os valores percentuais de perdas de água relativos à precipitação pluvial total decresceram anualmente, aproximando-se dos valores observados em FN. A partir do $5^{\circ}$ ano após implantação dos sistemas de eucalipto o comportamento dos

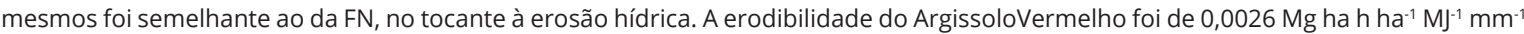
e o fator C apresentou valores de 0,121, 0,016 e 0,015 para FE1, FE2 e FN, respectivamente.
\end{abstract}

Termos para indexação: Erosão hídrica; erodibilidade do solo; erosividade da chuva; fator cobertura e manejo.

\section{INTRODUCTION}

Brazil possesses a large area occupied by eucalyptus plantations, which reaches approximately 5.6 million hectares (IBA, 2015). The Brazilian forest sector presents a great economic importance to the country, because it generates products for internal consumption and for exportation, especially in the paper and hardwood pulp sector, in which Brazil is the largest producer of market hardwood pulp (Castanho Filho, 2009). Moreover, the planted forest sector is responsible for $1.1 \%$ of the total Brazilian gross domestic product (GDP), and 5.5\% of the industrial GDP (IBA, 2015). Nevertheless, the 
environmental impacts caused by the extensive eucalyptus plantations in Brazil have been the subject of a great deal of discussions and controversies. Hence, scientific research is necessary in order to assess the possible environmental impacts caused by eucalyptus plantations in Brazil.

Eucalyptus has been often used for reforestation in sensitive areas, already degraded by previous use, with poor soils and located on steep hillslopes. These factors, associated with management operations, intensive mechanization, construction and maintenance of unpaved roads, contribute to the formation of very erosion-prone environments (Silva et al., 2014). Water erosion has been described as the main cause of land degradation in the world (Pimentel, 2006). In addition to the negative effects of on-site erosion, such as the decrease of soil fertility and soil organic matter, the contamination and sedimentation of water courses, due to off-site erosion impacts, compromise water resources.

Given the environmental issues that have been linked to extensive eucalyptus plantations, coupled with the increasing expansion of such forests in Brazil, the study of soil and water losses in eucalyptus cultivation systems is fundamental regarding soil conservation planning.

Water erosion can be monitored directly in the field by experimental erosion plots. However, such method is severely limited by the high costs and time expenses involved in the process. Hence, erosion prediction models have been used in order to estimate soil and water losses based on local parameters, enabling the identification of erosion-prone areas (Silva et al., 2014; Panagos et al., 2015)

The Universal Soil Loss Equation (USLE) (Wischmeier; Smith, 1978) is the most widely used erosion prediction model in the world, possibly due to the low input data required by the direct model equation (Kinnell, 2010). USLE is composed by numerical factors which represent the components that influence water erosion: rainfall erosivity - R, soil erodibility - K, topographical factor - LS, cover-management - C and support practices - P. Since USLE is an empirical model, the equation factors must be calibrated to specific conditions. Given the continental extension of Brazil, and the great environmental variability observed in the country, the development of a complete USLE database is challenging.

One of the greatest limitations of erosion modeling at large scales is the shortage of soil characterization data (Panagos et al., 2014). The USLE K factor is preferably determined by direct field measurements (Kinnell, 2010), requiring several years of erosion plot data. However, considering the great variability of Brazilian soils, few studies in the country have been conducted in order to determine $\mathrm{K}$ factor values by direct methods (Marques et al., 1997a; Bertol et al., 2007, Silva et al., 2009; Martins et al., 2011; Eduardo et al., 2013). Moreover, very rare studies have determined the $\mathrm{C}$ factor for eucalyptus plantations in Brazil: Martins et al. (2010) in the state of Espirito Santo e Silva et al. (2014) in the state of Minas Gerais.

The climatic factor of greatest importance regarding soil erosion in Brazil is rainfall, represented by the R factor in the USLE (Bertoni; Lombardi Neto, 2012). Rainfall erosivity is influenced by rainfall characteristics such as intensity, amount, frequency and distribution. Zhou et al. (2002) have demonstrated the strong relation existing between the intensity of rainfall and sediment production in river basins. However, such relation is site specific and presents a great variation among different regions. In the state of Rio Grande do Sul, rainfall erosivity values range from 5.135 to $11.217 \mathrm{MJ} \mathrm{mm} \mathrm{ha}{ }^{-1} \mathrm{~h}^{-1} \mathrm{yr}^{-1}$ (Oliveira; Wendland; Nearing, 2013).

The economic and environmental damages provoked by erosive processes have motivated the conduction of studies which monitor water erosion in planted eucalyptus forests, in different regions and under different soil classes and management techniques. Namely: Cardoso et al. (2004) and Martins et al. (2010) in the state of Espirito Santo, Brito et al. (2005), Pires et al. (2006), Silva et al. (2011) and Silva et al. (2014) in the state of Minas Gerais, Cândido et al. (2014), in Mato Grosso do Sul, and Oliveira et al. (2013) in Rio Grande do Sul.

Considering the scarcity of studies about water erosion in eucalyptus forests in the state of Rio Grande do Sul, which lies under strong pressure of silvicultural activities (Sell; Figueiró, 2012), the survey of scientific data is relevant to strengthen the discussions on the subject. In addition, the field research for the determination of the USLE factors on different soils classes, land uses and climatic conditions in Brazil is very important to the formation of a consistent USLE database, still incipient in Brazil. Such database will make it possible to carry out more accurate assessments of soil and water losses using USLE, assisting the pursuit of the sustainability of agro-ecosystems and enabling the choice of management practices that reduce the impact of agricultural activities.

Thus, the aim of this study was to evaluate soil and water losses by water erosion in eucalypt forests at different development stages, and to compare such losses to the ones in native forests and bare soils; and also, to contribute to the formation of a consistent USLE database in Brazil, determining the $\mathrm{K}, \mathrm{C}$ and $\mathrm{R}$ factors at a pilot sub-basin with forest systems in the city of Eldorado do Sul, RS. 


\section{MATERIAL AND METHODS}

The study area consisted of a pilot sub-basin, located in the Terra Dura forest, in the city of Eldorado do Sul - RS. It covers an area of 101.9 hectares, comprised by the UTM coordinates 440,902 and 441,931E and 6,662,028 and 6,660,462 S (Datum SAD 69, Zone 22J) (Figure 1).

The climate in the study area, according to the Köppen classification, is of the Cfa type: humid subtropical, characterized by warm summers and rainfall during the all the months of the year. The average annual rainfall is of 1,400 $\mathrm{mm}$ (Bergamaschi et al., 2013).

Eucalyptus plantations are the main land use. The forests are contour-planted, spaced $3 \times 3 \mathrm{~m}$. The soil preparation consisted of soil chiseling and subsoiling at a $60 \mathrm{~cm}$ depth, with minimum tillage. Residues from the previous harvest, such as stump, leaf, twigs and wood from the tree tips, remained in the area.

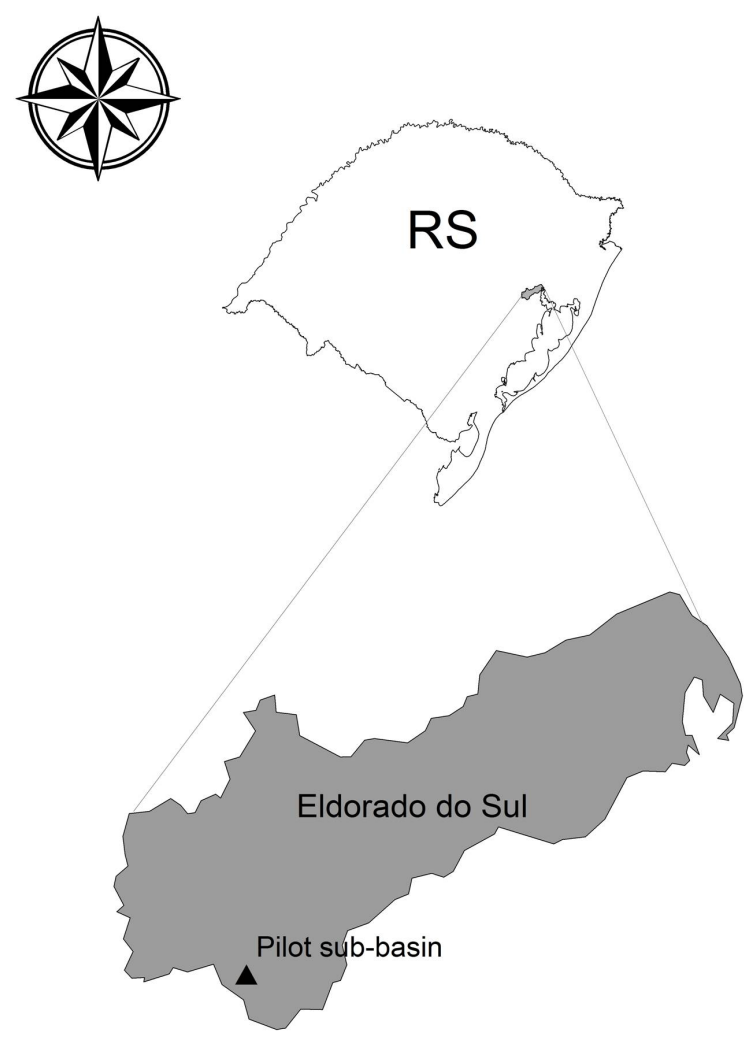

Rainfall erosivity was calculated based on rainfall data comprised during the period of October 2007 to December 2012. A rain gauging station located at the sub-basin provided rainfall precipitation values with a 30 min resolution. We considered individual rainstorm events as those separated from each other for more than a six-hour interval. Events with a total amount of rainfall lower than $10 \mathrm{~mm}$, with a maximum intensity lower than $24 \mathrm{~mm} \mathrm{~h}^{-1}$ in $15 \mathrm{~min}$, or with a total kinetic energy inferior to $3.6 \mathrm{MJ} \mathrm{ha}^{-1}$, were considered non-erosive (De Maria, 1994). The kinetic energy of each rainfall event was obtained by applying Equation 1, adapted by Foster et al. (1981):

$\mathrm{E}=0.119+0.0873 \log \mathrm{I}$

Where: $\mathrm{E}$ is the kinetic energy $\left(\mathrm{MJ} \mathrm{ha}^{-1} \mathrm{~mm}^{-1}\right)$, and $\mathrm{I}$ is the rain intensity $\left(\mathrm{mm} \mathrm{h}^{-1}\right)$.

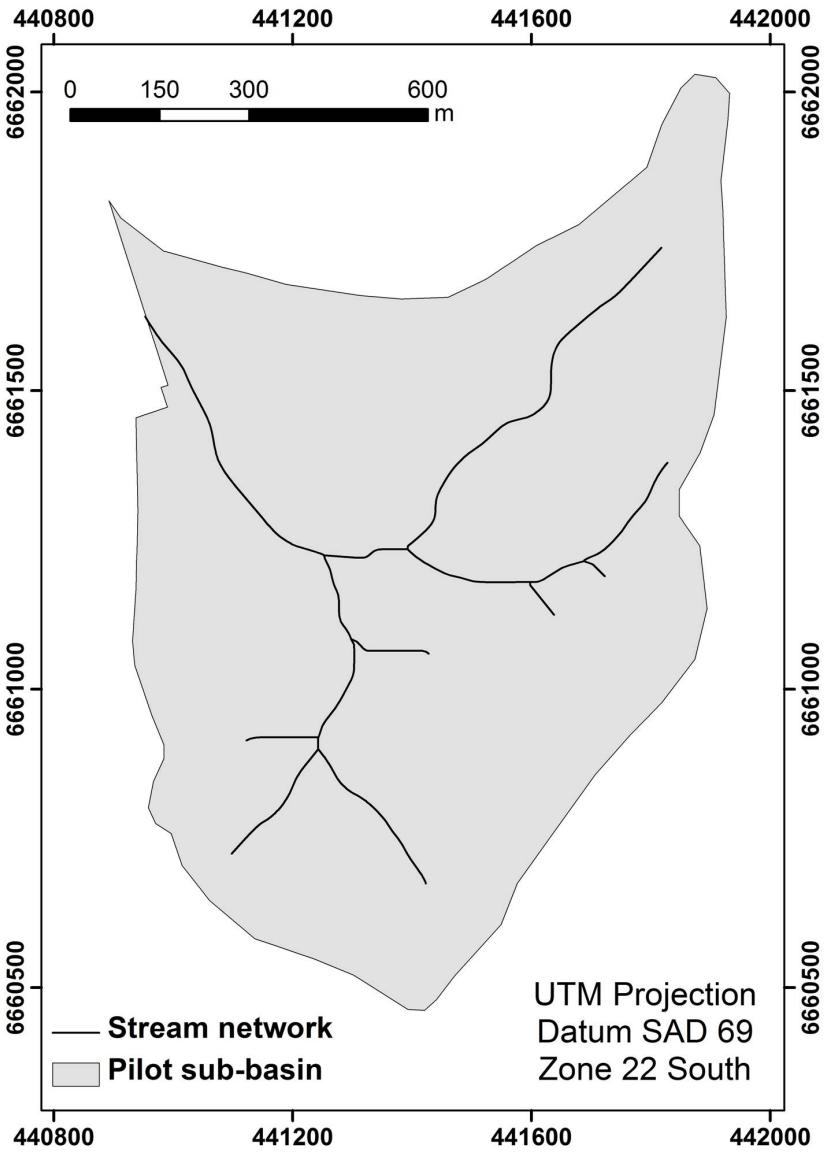

Figure 1: Location of the pilot sub-basin, at the city of Eldorado doSul, RS. 
The $\mathrm{EI}_{30}$ index was calculated by multiplying the total kinetic energy (E) of each erosive rainfall event by the maximum intensity occurred in a period of 30 consecutive minutes $\left(\mathrm{I}_{30}\right)$ (Wischmeier; Smith, 1978). The annual $\mathrm{EI}_{30}$ index values were calculated for each analyzed year, and their average was used as the $\mathrm{R}$ factor for the location, as suggested by Wischmeier and Smith (1978).

The soil losses were evaluated on a latosolic Distrofic Red Argisol (PVd). For soil characterization, samples were collected at the $0.0-0.2 \mathrm{~m}$ layer, with three replications. The chemical analyses were carried out according to Embrapa (1997). Bulk density (BD) and particle density (PD) were determined according to Blake and Hartge (1986a) and Blake and Hartge (1986b), respectively. The soil texture was evaluated by the Bouyoucos method and soil permeability was measured in the field using the Guelph permeameter (Reynolds; Vieira; Topp, 1992) (Table 1).

Erosion plots were used to study four land use treatments: Eucalyptus saligna hybrid clone plantation, established in 2004 (EF1); E. urophylla, E. maidenii, E. globules hybrid clone plantation, established in 2001 (EF2); native forest (NF), as a reference of a system in equilibrium; and bare soil (BS), initially tilled and kept fallow through periodic hand hoeing, as a reference of maximum soil losses.

In the eucalyptus treatments, three erosion plots were installed in the field, and one erosion plot was used for the NF and BS treatments. The experiment initiated in November 2006. However, in this study, we considered the data collected from 2007 onwards, in order to disconsider the influence of soil revolving during the establishment of the erosion plots.

The erosion plots were installed with dimensions of $4.0 \times 24.0 \mathrm{~m}$ in EF1 and EF2, and $4.0 \times 12.0 \mathrm{~m}$ in NF and BS. The greatest dimension of the plots was placed downslope, at $20 \%$ slope steepness.

At the lower end of each plot, gutter pipes were placed in order to conduct the runoff to the collector tanks. After each rainfall event with runoff formation, the water height at the collector tanks was measured. The runoff was sampled in the tanks, with three replications per tank. The samples were decanted at the laboratory and dried in a bench oven at $105^{\circ} \mathrm{C}$, in order to estimate sediment concentration. The soil volume in the collector tank (determined based on the runoff samples and particle density) was deducted from the total runoff volume to determine the water losses.

The soil erodibility $(\mathrm{K})$ of the PVd was determined based on erosivity (x) and soil losses (y) data obtained in the BS plot, by simple linear regression $(y=a+b x)$, following Wischmeier and Mannering procedure (1969). The linear regression was adjusted so that the initial coordinates of the regression line would depart from the origin. Hence, the adjusted model is used in the form $y=b x$, where the $b$ coefficient, after adjustment to standard unit plot conditions (Wischmeier; Smith, 1978), stands for the soil erodibility.

The adjustment to unit plot conditions ( $9 \%$ slope and $22.13 \mathrm{~m}$ slope-length) was performed according to Equation 2 (Bertoni; Lombardi Neto, 2012):

$$
\mathrm{LS}=0.01 \mathrm{~L}^{0,5}\left(1.36+0.975 \mathrm{~S}+0.13855 \mathrm{~S}^{2}\right)
$$

where: LS is the topographic factor (dimensionless); L is the slope length (m) and $\mathrm{S}$ is the slope steepness (\%).

Based on the erosion plot data, the soil loss ratio (SLR) for EF1, EF2 and NF was determined. The calculation of the SLR was performed according to Wischmeier and Smith (1978), using the Equation 3:

\section{$\mathrm{SLRi}=\mathrm{PCi} / \mathrm{PDi}$}

Where: SLR is the soil loss ratio; i is the developmental stage of the eucalyptus and NF treatments, PC is the soil loss in the treatments $\left(\mathrm{Mg} \mathrm{ha}^{-1}\right.$ year $\left.^{-1}\right)$ and $\mathrm{PD}$ is the soil loss for BS $\left(\mathrm{Mg} \mathrm{ha}^{-1}\right.$ year $\left.^{-1}\right)$.

With the SLR values and the distribution of rainfall erosivity, the $\mathrm{C}$ factor values for EF1, EF2 and NF were calculated as Equation 4:

Table1: Physical and chemical properties of the $0.0-0.2 \mathrm{~m}$ layer of the latosolic Distrofic Red Argisol.

\begin{tabular}{ccccccccccc}
\hline BD & PD & Clay & Silt & Sand & GMD & Textural gradient & BS & ECEC & OC & Perm. \\
\hline$\ldots . . \mathrm{Kg} \mathrm{dm}^{-3} \ldots$ & $\ldots \ldots \ldots \ldots \ldots \ldots \ldots \ldots \ldots \ldots \ldots$ & $\mathrm{mm}$ & & & $\ldots . . \mathrm{cmol}_{\mathrm{c}} \mathrm{dm}^{-3} .$. & $\mathrm{g} \mathrm{Kg}^{-1}$ & $\mathrm{~mm} \mathrm{~h}^{-1}$ \\
\hline 1.7 & 2.5 & 24 & 14 & 62 & 4.5 & 2.9 & 1.7 & 2.9 & 9.0 & 50 \\
\hline
\end{tabular}

BD: bulk density, PD: particle density, GMD: geometric mean diameter, Textural gradiente: clay B horizon/clay A horizon, BS: base sum, ECEC: effective cation exchange capacity, OC: organic carbon, Perm: soil permeability. 
$\mathrm{C}=\Sigma(\mathrm{SLRi} \mathrm{xEi}) / \mathrm{E}$

(4)

Where: $\mathrm{C}$ is the cover-management factor, SLRi is the ratio of soil losses at the developmental stage of the eucalyptus and NF treatments, Ei is the rainfall erosivity at such stage and $\mathrm{E}$ is total erosivity.

\section{RESULTS AND DISCUSSION}

During the experimental period, a total of 451 rainfall events were analyzed, of which $43 \%$ were considered erosive and $57 \%$ non-erosive. The average rainfall erosivity for the study period was of $4,228.52$
MJ mm ha ${ }^{-1} h^{-1}$ year-1 $^{-1}$ (Table 2). Such value is below the $\mathrm{R}$ factor determined for Rio Grande city, located in the southeast of the RS state, estimated as 5,135 MJ $\mathrm{mm} \mathrm{ha}^{-1} \mathrm{~h}^{-1}$ year ${ }^{-1}$ (Bazzano; Eltz; Cassol, 2010).

The months of September, April and November showed the highest average monthly erosivity values during the period (Figure 2), corresponding to $40 \%$ of the total average annual erosivity. Such months presented average erosivity values greater than $500 \mathrm{MJ} \mathrm{mm} \mathrm{ha}^{-1}$ $\mathrm{h}^{-1}$ month $^{-1}$, which is considered critical by Rufino (1986). During such period, tillage and other mechanical operations, which may expose the soil, should be carefully planned in order to prevent severe soil and water losses.

Table 2: Annual values of rain erosivity and soil $\left(\mathrm{Mg} \mathrm{ha}^{-1}\right)$ and water losses ( $\mathrm{mm}$ ) in latosolic Distrophic Red Argisol under different land uses.

\begin{tabular}{|c|c|c|c|c|c|c|c|c|c|c|c|}
\hline \multirow{3}{*}{ Years } & \multirow{3}{*}{$\frac{\text { Erosivity }}{\mathrm{MJ} \mathrm{mm} \mathrm{ha}^{-1} \mathrm{~h}^{-1} \text { year }^{-1}}$} & \multirow{3}{*}{$\begin{array}{l}\text { Erosive } \\
\text { events }\end{array}$} & \multirow{3}{*}{$\begin{array}{l}\text { Non- } \\
\text { erosive } \\
\text { events }\end{array}$} & \multicolumn{8}{|c|}{ Soil and water losses } \\
\hline & & & & \multicolumn{2}{|c|}{ EF1 } & \multicolumn{2}{|c|}{ EF2 } & \multicolumn{2}{|c|}{ BS } & \multicolumn{2}{|c|}{ NF } \\
\hline & & & & $\mathrm{Mg} \mathrm{ha}^{-1}$ & $\mathrm{~mm}$ & $\mathrm{Mg} \mathrm{ha}^{-1}$ & $\mathrm{~mm}$ & $\mathrm{Mg} \mathrm{ha}^{-1}$ & $\mathrm{~mm}$ & $\mathrm{Mg} \mathrm{ha}^{-1}$ & $\mathrm{~mm}$ \\
\hline 2007 & $1126.8^{*}$ & 9 & 16 & 2.21 & 450 & 0.29 & 273 & 13.89 & 1167 & 0.03 & 40 \\
\hline 2008 & 3315.6 & 34 & 39 & 0.51 & 278 & 0.10 & 143 & 5.03 & 921 & 0.02 & 28 \\
\hline 2009 & 6503.4 & 45 & 41 & 1.82 & 318 & 0.12 & 176 & 6.26 & 852 & 0.25 & 54 \\
\hline 2010 & 3197.6 & 36 & 44 & 0.23 & 304 & 0.10 & 123 & 2.37 & 573 & 0.03 & 47 \\
\hline 2011 & 4358.8 & 34 & 35 & 0.07 & 84 & 0.10 & 61 & 26.99 & 1012 & 0.04 & 25 \\
\hline 2012 & 3767.2 & 34 & 84 & 0.02 & 19 & 0.01 & 23 & 17.65 & 338 & 0.01 & 13 \\
\hline Total & 21142.6 & 192 & 259 & 4.86 & 1453 & 0.72 & 799 & 72.19 & 4863 & 0.38 & 207 \\
\hline Mean & 4228.52 & 32 & 43 & 0.81 & 242 & 0.12 & 133 & 12.03 & 811 & 0.06 & 35 \\
\hline
\end{tabular}

*Data comprised solely during the months of October, November and December. BS: bare soil; EF1: eucalyptus plantation established in 2004; EF2: eucalyptus plantation established in 2001; NF: native forest.

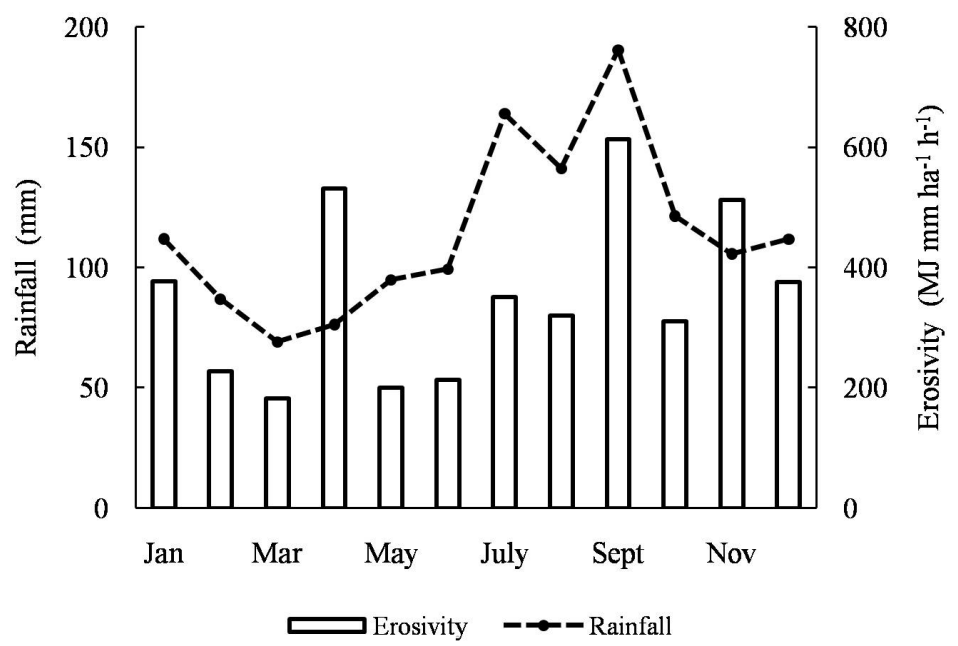

Figure 2: Monthly average rainfall and erosivity, in the period from 2007 to 2012 at the sub-basin pilot. 
The average monthly rainfall was greater in September, July and August, respectively (Figure 2). However, average rainfall erosivity in the months of July and August did not reflect such trend, most possibly due to the occurrence of lower intensity rainfall events. Studies conducted by Mello et al. (2007) and Oliveira et al. (2012) demonstrate that high levels of annual rainfall do not necessarily translate to high erosivity. Greater erosivity values are influenced by intensive rainfall that occurs at certain periods of the year (Oliveira; Wendland; Nearing, 2013). In a similar study, Cassol et al. (2008) reported the lowest monthly rainfall erosivity during July and August, at the municipality of São Borja, RS.

The soil and water losses among the analyzed treatments showed the same trend: $\mathrm{BS}>\mathrm{EF} 1>\mathrm{EF} 2>\mathrm{NF}$ (Table 2). The average annual soil losses ranged from 0.06 $\mathrm{t} \mathrm{ha}^{-1}$ year $^{-1}$ (NF) to $12.03 \mathrm{t} \mathrm{ha}^{-1}$ year $^{-1}$ (BS). The average annual water losses ranged from $35 \mathrm{~mm}$ (NF) to $811 \mathrm{~mm}$ (BS) (Table 2). Such behavior demonstrates, as expected, the greatest propensity to runoff formation and soil erosion on the BS, especially in contrast to the low soil and water losses observed in the NF, which is the reference of system in equilibrium.

The total soil losses in EF1 and EF2 were about 15 and 100 times lower, respectively, than those observed in BS; whereas the total water losses, in such treatments, were 3 and 6 times lower than the ones in BS, respectively (Table 2).

Among the eucalyptus treatments, the lowest soil and water losses observed in EF2 reflect the discrepancy of forest development stages between $\mathrm{EF} 1$ and $\mathrm{EF} 2$, given that the EF2 forest was planted three years before EF1. Hence, during the beginning of the experiment, forest canopy and litter accumulation in EF2 was much greater than in EF1.

None of the treatments showed a gradual and steady decrease of annual soil losses, even with the progressive development of the canopy of the planted forests. Such behavior stems from the influence of rainfall erosivity. For example, the annual soil losses in EF1 and EF2 increased from 2008 to 2009, as an effect of greater rainfall erosivity in the latter year. In the NF treatment, annual soil losses were low during the whole studied period. In such case, the annual variation of soil losses, although small, strongly reflects rainfall erosivity fluctuations. A trend of reduction/stabilization of soil losses could be observed from the 5 th year on after the establishment of the eucalyptus forests, when soil losses in EF1 and EF2 become close to the ones in the NF (Table 2). A similar result was reported by
Martins et al. (2003), who detected a downward trend in soil and water losses from the 3 rd to the 4th year after the eucalyptus planting. According to such authors, soil losses in eucalyptus plantations approximate those from native forests only from the 5 th year onwards.

The greatest soil losses in the BS occurred in the years of 2011 and 2012, despite the fact that such years did not present the highest annual erosivity values during the studied period. Such behavior can be explained by the occurrence of isolated rainfall events with high erosive potential, contributing to the expressive soil losses observed these years. In the forested treatments, the effect of such highly erosive events was attenuated due to the soil protection already consolidated by the vegetation.

The soil loss tolerance for the studied soil class (PVd), calculated by Oliveira et al. (2013), is of $12.9 \mathrm{Mg}$ ha $^{-1}$ year ${ }^{-1}$. The soil loss values for the eucalyptus forests lie quite below the such tolerance threshold, corroborating studies the of Martins et al. (2003), Brito et al. (2005), Pires et al. (2006), Martin et al. (2010), Oliveira et al. (2013) and Cândido et al. (2014), which indicate the adequacy of the eucalyptus systems in relation to water erosion.

The percentage of water losses in relation to the total rainfall decreased annually in EF1 and EF2, declining from 30 to $4 \%$ and from 18 to $4 \%$, respectively, along the studied period (Figure 3). Such values came close, in 2011 and 2012, to the ones obtained in the NF plot. In the NF treatment, the annual water loss ratio remained rather constant, alternating between 2 and $3 \%$, being little influenced by the variation of annual rainfall (Figure 3), which indicates the importance of native vegetation regarding water infiltration and water recharge.

Apart from the soil protection provided by the forest canopy, the eucalyptus contour planting and the maintenance of crop residues on the soil surface contribute towards the reduction of surface runoff and soil and water losses. Scientific studies have shown that raindrops reach the soil surface with a high kinetic energy in uniform forest areas, due to the coalescence of raindrops along the canopy (Cao et al ., 2015). These results highlight the importance of litter and of the maintenance of crop residues in planted forest areas (Geißleret al., 2012, Cao et al., 2015).

In the BS, the water losses corresponded up to $79 \%$ of the total annual rainfall (Figure 3 ). The high water losses observed on fallow soils in this study highlight the importance of adopting conservation practices that promote water infiltration, such as terracing, contour 
planting and maintenance of crop residues. Such practices can contribute to lower water losses after harvest and tillage operations, when the soil is bare and more susceptible to surface runoff formation. While assessing water erosion in different soil tillage methods in Eldorado do Sul - RS, Castro, Cogo and Volk (2006) found similar results in a Red Argisol, under simulated rainfall, with average water losses equivalent to $80 \%$ of the total rainfall.

In order o determine the $\mathrm{K}$ factor for the studied soil class (PVd), the linear regressions between rainfall erosivity and soil losses were grouped annually (Figure 4). The correlation coefficients ranged from 0.37 to 0.90 (Figure 4). In a similar work, Eduardo et al. (2013) obtained correlation coefficients ranging from 0.49 to 0.74 for a Red Yellow Argisol.

The $\mathrm{K}$ factor values, calculated for each year, varied significantly during the study period, with

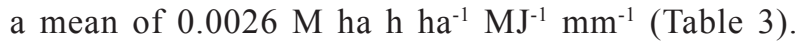
According to Bertol et al. (2007), such variability can be caused by several factors, such as climate variability and the irregularity of previous soil moisture conditions.

The $\mathrm{K}$ factor value found in this study is quite below the ones determined for Red Podzolics, compiled by Marques et al. (1997b). The K factor of a Red Yellow Argisol, of $0.0106 \mathrm{Mg}$ ha $\mathrm{h} \mathrm{ha}^{-1} \mathrm{MJ}^{-1} \mathrm{~mm}^{-1}$, reported by Eduardo et al. (2013), is also higher than the one obtained in this study. However, Martins et al. (2011) estimated an erodibility of $0.007 \mathrm{Mg}$ ha h ha-1 $\mathrm{MJ}^{-1} \mathrm{~mm}^{-1}$ for a medium/ clayey Yellow Argisol, which is relatively close to the value obtained in this study.

The determined erodibility for the PVd is in the range of values compiled by Silva et al. (2000) for Latosols, approaching the values obtained by Hernani et al. (1997), Marques et al. (1997a) and Silva et al. (2009) for such soil class. The PVd from this study is an intermediate Argisol (Latosolic at the 4th categorical level), i.e., it is an Argisol with some properties of Latosols. The high sand content in the surface layer (Table 1) contributes to increase water infiltration in the soil, which presented a permeability of $50 \mathrm{~mm} \mathrm{~h}^{-1}$. The permeability determined for this PVd approaches the results obtained by Nunes et al. (2012) and Sales et al. (1999) for Latosols. Such results highlight the importance of conducting erosion field research to determine the erodibility of Brazilian soils. The great variability of climate and soil characteristics result into largely distinct erodibility values among soils, even within a same general soil class.

The values obtained for the $\mathrm{C}$ factor in $\mathrm{EF} 1, \mathrm{EF} 2$ and NF were of $0.121,0.016$ and 0.015 , respectively (Table 4). The high rainfall erosivity observed during the year of 2009 caused major losses in EF1, a fact which was not observed in EF2 and NF. That stems from the fact the latter two treatments were already at a more developed stage at the time. The $\mathrm{C}$ factor for EF1 represents more adequately the whole cycle of the eucalyptus, which is usually harvested for pulpwood about seven years after planting.

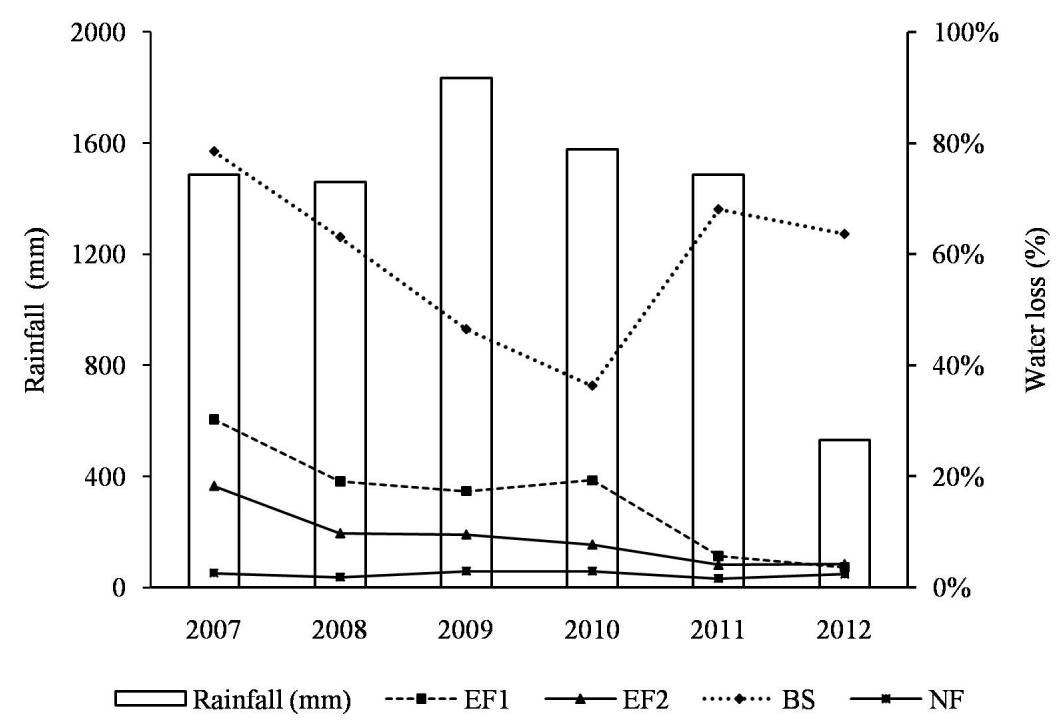

Figure 3: Percentage of water losses in relation to the annual precipitation in the analyzed treatments. 
a)

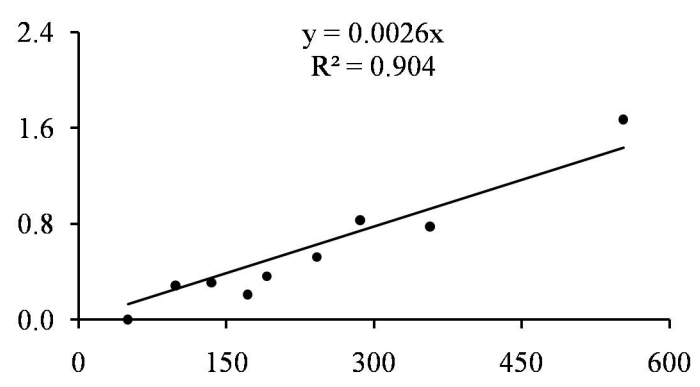

c)

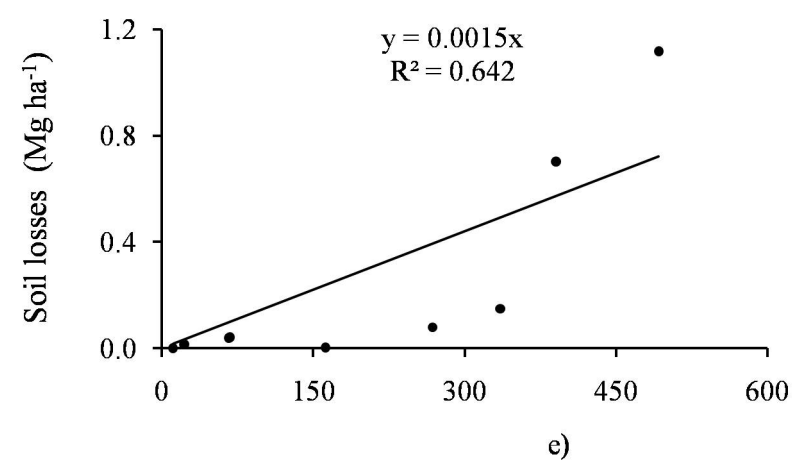

e) b)

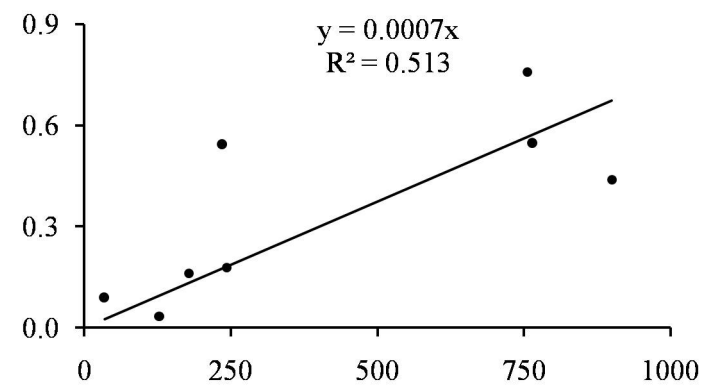

d)

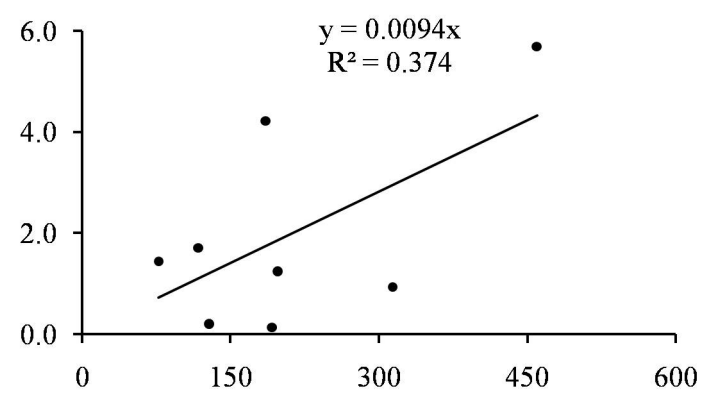

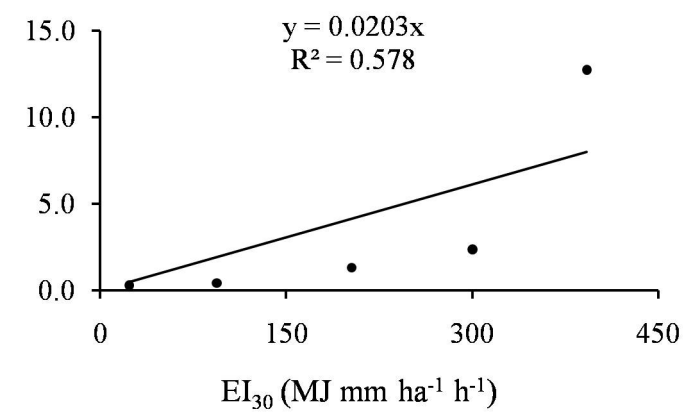

Figure 4: Relation of soil losses (BS) and rain erosivity ( $\left.\mathrm{EI}_{30}\right)$ in the period: 2008 (a), 2009 (b), 2010 (c), 2011 (d) and January to July 2012 (e), for the latosolic Distrophic Red Argisol.

Table 3: Annual erodibility values for the latosolic Distrophic Red Argisol, under natural rainfall, in the period from 2008 to 2012, at the pilot sub basin.

\begin{tabular}{cc}
\hline \multirow{2}{*}{ Year } & Factor $\mathrm{K}$ \\
\cline { 2 - 2 } 2008 & Mg ha h ha-1 $\mathrm{MJ}^{-1} \mathrm{~mm}^{-1}$ \\
2009 & 0.0010 \\
2010 & 0.0003 \\
2011 & 0.0006 \\
2012 & 0.0036 \\
Mean & 0.0077 \\
\hline
\end{tabular}

Table 4: Soil Loss Rate (SLR) and cover-management factor (C) for the different land uses at the pilot subbasin, in the period from 2008 to 2012.

\begin{tabular}{ccccccc}
\hline \multirow{2}{*}{ Year } & \multicolumn{3}{c}{ SLR } & \multicolumn{3}{c}{$C$} \\
\cline { 2 - 7 } & EF1 & EF2 & NF & EF1 & EF2 & NF \\
\hline 2008 & 0.101 & 0.020 & 0.004 & 0.016 & 0.003 & 0.001 \\
2009 & 0.291 & 0.019 & 0.040 & 0.089 & 0.006 & 0.012 \\
2010 & 0.097 & 0.042 & 0.013 & 0.015 & 0.006 & 0.002 \\
2011 & 0.003 & 0.004 & 0.001 & 0.001 & 0.001 & 0.000 \\
2012 & 0.001 & 0.001 & 0.001 & 0.000 & 0.000 & 0.000 \\
\hline Total & 0.493 & 0.086 & 0.059 & 0.121 & 0.016 & 0.015 \\
\hline
\end{tabular}


A C factor for eucalyptus plantations of 0.12 was suggested by Silva et al. (2014), who also reported a 0.09 value for native forests. Although such values are similar to the ones obtained in this study, Martins et al. (2010) reported a quite higher $\mathrm{C}$ factor value for eucalyptus forests, of 0.30 . Nevertheless, the $\mathrm{C}$ factor of 0.02 for native vegetation, reported by such authors, is similar to the one determined is this study. The $\mathrm{C}$ factors determined in this study, for both eucalyptus and native forests, are above the established range for forests in Europe, which varies from 0.0001 to 0.003 (Panagos et al., 2015).

\section{CONCLUSIONS}

The average annual erosivity at the sub-basin was of 4,228.52 MJ mm ha ${ }^{-1} \mathrm{~h}^{-1}$ year-1. The months of April, September and November presented the highest average monthly erosivity values. The average annual soil losses in EF1 and EF2 (0.81 and $0.12 \mathrm{Mg} \mathrm{ha}^{-1}$ year $^{-1}$, respectively) were below of the limit of tolerance for the PVd, of $12.9 \mathrm{Mg} \mathrm{ha}^{-1}$ year ${ }^{-1}$. There was a trend of reduction/stabilization of soil losses after the 5 th year of the eucalyptus cycle, with losses close to those observed at the native forest. The percent values of water losses relative to the total rainfall decreased annually in EF1 and EF2, approaching the values observed in NF (3\%). The results presented in this study highlight the potential of eucalyptus reforestation, combined with the adoption of soil conservation practices, for controlling water erosion. After six years of experimental plot-data, an erodibility of $0.0026 \mathrm{Mg}$ ha h ha ${ }^{-1} \mathrm{MJ}^{-1} \mathrm{~mm}^{-1}$ was determined for the PVd. The C factor for the EF1, EF2 and NF treatments were of $0.121,0.016$ and 0.015 , respectively.

\section{ACKNOWLEDGMENTS}

This research was funded in part by the Coordination of Superior Level Staff Improvent - CAPES; the National Counsel of Technological and Scientific Development - CNPq (Processes 471522/2012-0 and 305010/2013-1); and the Minas Gerais State Research Foundation - FAPEMIG (Process GAG-PPM-00422-13). The authors are thankful to CMPC Celulosa for the field assistance and data collection; and also to the anonymous reviewers which greatly contributed to this paper.

\section{REFERENCES}

BAZZANO, M. G. P.; ELTZ, F. L. F.; CASSOL, E. A. Erosividade e características hidrológicas das chuvas de Rio Grande (RS). Revista Brasileira de Ciência do Solo. 34(1):235-244, 2010.
BERGAMASCHI, $\mathrm{H}$. et al. Boletins agrometeorológicos da estação experimental agronômica da UFRGS - série histórica 1970 - 2012. Porto Alegre, RS: UFRGS, 2013. Available in: <http://www.ufrgs.br/agronomia/joomla/ files/EEA/Srie_Meteorolgica_da_EEA-UFRGS.pdf>. Acess in: June, 15, 2014.

BERTOL, I. et al. Erodibilidade de um Nitossolo Háplico alumínico determinada em condições de campo. Revista Brasileira de Ciência do Solo. 31(3):541-549, 2007.

BERTONI, J.; LOMBARDI NETO, F. Conservação do solo. São Paulo: Editora Ícone, 2012. 355p.

BLAKE, G. R.; HARTGE, K. H. Bulk density. In: KLUTE, A. Methods of soil analysis. Madison: American Society of Agronomy, 1986a. p.363-375.

BLAKE, G. R.; HARTGE, K. H. Particle density. In: KLUTE, A. Methods of soil analysis. Madison: American Society of Agronomy, 1986b. p.377-382.

BRITO, L. F. et al. Erosão de Latossolo Vermelho muito argiloso relevo ondulado em área de pós-plantio de eucalipto no Vale do Rio Doce, região Centro Leste do estado de Minas Gerais. ScientiaForestalis. 67(1):27-36, 2005.

CÂNDIDO, B. M. et al. Erosão hídrica pós-plantio em florestas de eucalipto na bacia do rio Paraná, no leste do Mato Grosso do Sul. Revista Brasileira de Ciência do Solo. 38(5):1565-1575, 2014.

CAO, L. et al. Runoff and soil loss from Pinus massoniana forest in southern China after simulated rainfall. Catena. 129:1-8, 2015

CARDOSO, D. P. et al. Erosão hídrica avaliada pela alteração na superfície do solo em sistemas florestais. Scientia Forestalis. 66:25-37, 2004.

CASSOL, E. A. et al. Erosividade, padrões hidrológicos, período de retorno e probabilidade de ocorrência das chuvas em São Borja, RS. Revista Brasileira de Ciência do Solo. 32(3):1239-1251, 2008.

CASTANHO FILHO, E. P. Eucalipto: demanda crescente. Florestar Estatístico. 9(18):9-13, 2009.

CASTRO, L. G.; COGO, N. P.; VOLK, L. B. S. Alteracões na rugosidade superficial do solo pelo preparo e pela chuva e sua relação com a erosão hídrica. Revista Brasileira de Ciência do Solo. 30(2):339-352, 2006.

DE MARIA, I. C. Cálculo da erosividade da chuva. In: Manual de programas de processamento de dados de campo e de laboratório para fins de experimentação em conservação do solo. Campinas: IAC/SCS, 1994. 
EDUARDO, E. N. et al. Erodibilidade, fatores cobertura e manejo e práticas conservacionistas em Argissolo VermelhoAmarelo, sob condições de chuva natural. Revista Brasileira de Ciência do Solo. 37(3):796-803, 2013.

EMPRESA BRASILEIRA DE PESQUISA AGROPECUÁRIA EMBRAPA. Manual de métodos de análise de solos. Rio de Janeiro: Ministério da Agricultura, 1997. 212p.

FOSTER, G. R. et al. Conversion of the universal soil loss equation to SI units. Journal Soil Water Conservation. 36(6):355-359, 1981.

GEIßLER, C. et al. Splash erosion potential under tree canopies in subtropical SE China. Catena. 91:85-93, 2012.

HERNANI, L. C. et al. Perdas por erosão e rendimentos de soja e de trigo em diferentes sistemas de preparo de um Latossolo Roxo de Dourados (MS). Revista Brasileira de Ciência do Solo. 21(4):667-676, 1997.

INDÚSTRIA BRASILEIRA DE ÁRVORES - IBÁ. Relatório Ibá 2015. Available in: http://iba.org/images/shared/iba_2015.pdf. Access in: May, 02, 2016

KINNELL, P. I. A. Event soil loss, runoff and the Universal Soil Loss Equation family of models: A review. Journal of Hydrology. 385(1):384-397, 2010.

MARQUES, J. J. G. S. M. et al. Índices de erosividade da chuva, perdas de solo e fator erodibilidade para dois solos da região dos cerrados - primeira aproximação. Revista Brasileira de Ciência do Solo. 21(3):427-34, 1997a.

MARQUES, J. J. G. S. M. et al. Adequação de métodos indiretos para estimativa da erodibilidade de solos com horizonte $B$ Textural no Brasil. Revista Brasileira de Ciência do Solo. 21(3):447-456, $1997 \mathrm{~b}$.

MARTINS, S. G. et al. Perdas de solo e água por erosão hídrica em sistemas florestais na Região de Aracruz (ES). Revista Brasileira de Ciência do Solo. 27(3):395403, 2003.

MARTINS, S. G. et al. Fator cobertura e manejo do solo e perdas de solo e água em cultivo de eucalipto e em Mata Atlântica nos Tabuleiros Costeiros do estado do Espírito Santo. Scientia Forestalis. 38(87):517-526, 2010.

MARTINS, S. G. et al. Erodibilidade do solo nos Tabuleiros Costeiros. Pesquisa Agropecuária Tropical. 41(3):322327, 2011.

MELLO, C. R. et al. Monthly and annual rainfall erosivity for Minas Gerais State. Pesquisa Agropecuária Brasileira. 42(4):537-545, 2007.
NUNES, J. A. S. et al. Velocidade de infiltração pelo método do infiltrômetro de anéis concêntricos em Latossolo Vermelho de Cerrado. Enciclopédia Biosfera. 8(15):16851692, 2012.

OLIVEIRA, P. T. S. et al. Spatial variability of the rainfall erosive potencial in the State of Mato Grosso do Sul, Brazil. Engenharia Agrícola. 32(1):69-79, 2012.

OLIVEIRA, P. T. S.; WENDLAND, E.; NEARING, M. A. Rainfall erosivity in Brazil: A review. Catena. 100:139-147, 2013.

OLIVEIRA, A. H. et al. Water erosion in soils under eucalyptus forest as affected by development stages and management systems. Ciência e Agrotecnologia. 37(2):159-169, 2013.

PANAGOS, P. et al. Soil erodibility in Europe: A highresolution dataset based on LUCAS. Science of The Total Environment. 479-480:189-200, 2014.

PANAGOS, P. et al. Estimating the soil erosion covermanagement factor at the European scale. Land Use Policy. 48:38-50, 2015.

PIMENTEL, D. Soil erosion: A food and environmental threat. Environment, Development and Sustainability. 8:119137, 2006.

PIRES, L. S. et al. Erosão hídrica pós-plantio em florestas de eucalipto na região centro-leste de Minas Gerais. Pesquisa Agropecuária Brasileira. 41(4):687-695, 2006.

REYNOLDS, W. D.; VIEIRA, S. R.; TOPP, G. C. An assessment of the single- head analyses for the constant head well permeameter. Canadian Journal of Soil Science. 72(4):489-501, 1992.

RUFINO, R. L. Avaliação do potencial erosivo da chuva para o Estado do Paraná: Segunda aproximação. Revista Brasileira de Ciência do Solo. 10(3):279-281, 1986.

SALES, L. E. O. et al. Estimativa da velocidade de infiltração básica do solo. Pesquisa Agropecuária Brasileira. 34(11):2091-2095, 1999.

SELL, J. K.; FIGUEIRÓ, A. S. Transformação da paisagem e impactos socioambientais no Bioma Pampa. Revista da ANPEGE. 7( 8):129-141, 2012.

SILVA, M. L. N. et al. Avaliação de métodos indiretos de determinação da erodibilidade de Latossolos brasileiros. Pesquisa Agropecuária Brasileira. 35(6):1207-1220, 2000. 
SILVA, A. M. et al. Erosividade da chuva e erodibilidade de Cambissolo e Latossolo na região de Lavras, sul de Minas Gerais. Revista Brasileira de Ciência do Solo. 33(6):18111820, 2009.

SILVA, M. A. et al. Sistemas de manejo em plantios florestais de eucalipto e perdas de solo e água na região do Vale do Rio Doce, MG. Ciência Florestal. 21(4):765-776, 2011.

SILVA, M. A. et al. Water erosion risk prediction in eucalyptus plantations. Ciência e Agrotecnologia. 38(2):160-172, 2014.
WISCHMEIER, W. H.; MANNERING, J. V. Relation of soil properties to its erodibility. Soil Science Society of America, Proceedings. 33:131-137, 1969.

WISCHMEIER, W. H.; SMITH, D. D. Predicting rainfall erosion losses: a guide to conservation planning. Washington: USDA, 1978. 537p.

ZHOU, G. Y. et al. Hydrological impacts of reafforestation with eucalypts and indigenous species: a case study in southern China. Forest Ecology and Management. 167(1):209-222, 2002. 